\title{
Tarihsel ve Teorik Açıdan Adalet Dairesinin Uzun Formu*
}

\section{The Long form of Circle of Justice in Terms of its Historical Background and Theoretical Principles}

\author{
Illker Kömbe \\ Istanbul Medeniyet Üniversitesi, Türkiye \\ ilkerkombe@gmail.com
}

Öz: Bu makalede, ortaçağ i̇slâm siyaset düşüncesini oluşturan pek çok siyaset türünde kaleme alınmış olan kitapların hem muhtevaları hem de bölüm başlıkları açısından en temel, en önemli ve en merkezi kavramı olan adalet dairesi, yalnızca uzun formu dikkate alınmak koşuluyla, başlangıcından Osmanlı dönemine ait XVI. yüzyılın sonuna kadarki bir dönemle sınırlı kalacak biçimde, söz konusu olan kavramın tarihsel süreci ve teorik arka planı veya ilkeleri olmak üzere, iki bakımdan, ele alınarak incelenmeye ve değerlendirilmeye gayret edilecektir. Tarihsel süreci açısından bakıldığında, birinci olarak, adalet dairesinin uzun formunun yer aldığı ilk kaynak ve uzun formun orta çağ İslâm siyaset düşüncesine ne şekilde ya da hangi yolla geçtiği tespit edilmeye ve bu tespitin ne anlama geldiği, bir başka ifadeyle, bu tespitten çıkan sonuç gösterilmeye çalışılacaktır. İkinci olarak, orta çağ ìslâm siyaset düşüncesinin altında yer alan çeşitli siyaset türlerinde adalet dairesinin uzun formuna yer veren kaynaklar, bu kaynakların yazıldıkları devletler ve coğrafyalar ile uzun formun nispet edildiği şahıslar ve temel unsurları ifade edilecektir. Kavramın Teorik arka planı veya dayanağı olan ilkeler açısından bakıldığında ise, birinci olarak, merkezî bir siyaset düşüncesi kavramı olan adalet dairesinin uzun formunun ilkeleri temellendirilmeye ve bu ilkelerin, Yeni Platoncu felsefe çerçevesinde kabul edilebilecek olan Meşşaî felsefenin klâsik bilişsel yahut rasyonel psikolojiye karşılık gelen nefs teorisi, ahlâk felsefesi, doğa felsefesi, evren ve kozmoloji anlayışı ile metafizikten nasıl kaynaklandığı gösterilmeye çalışılacaktır. Son olarak ise, adalet dairesinin uzun formunun, ilişkili olduğu devlet ve toplum düzeni ve yapısı ile bu devlet ve toplum yapısı ve düzeni içindeki önemi, anlamı ve işlevi analiz edilecektir.

Anahtar Kelimeler: Adalet Dairesi, Uzun Form, Sırrü’l-esrâr, Siyaset Düşüncesi, Düzen

ORC-ID: İç Kömbe 0000-0001-9405-1455

"Bu çalışma İbn Haldun Üniversitesi tarafından 20-21 Aralık 2019 tarihinde İstanbul'da düzenlenen "Uluslararası İslam'da Medeniyet Bilimleri Tarihi Sempozyumu" adlı bilimsel etkinlikte sunulan bildirinin gözden geçirilmiş halidir. 


\begin{abstract}
In this study or article, we will try to analyze and evaluate the long form of circle of justice which is the basic, importance and central concept of different kinds of politics that belong to Islamic political thought in terms of historical background and theoretical or philosophical principles from beginning to end of sixteenth century of Ottoman period. From a historical perspective, firstly, we will try to determine the first book that the long form of circle of justice is found in it and afterwards we will try to show how the long form introduced into Islamic political thought externally. Secondly, we will try to explain and show the different and several Islamic political works that discuss and explain the long form and its main elements as well as the different and several states and regions in which they were written. From a theoretical or philosophical perspective, firstly, we will try to analyze the basic principles of the long form which is the central concept of political thought. Secondly, we will try to show how its principles are derived from the classical psychological and ethical philosophy and view of nature as well as cosmology and metaphysics of Messsai philosophy that can be found acceptable in the extent of Neo Platonic philosophy. Finally, we will try to explain the kind of political thought, state and society that the long form belongs them and the meaning, importance and function of the long form in the structure and order of the state and society.
\end{abstract}

Keywords: Circle of Justice, Long Form, SIrru'l-esrar, Political Thought, Order.

\title{
Giriş
}

Bu çalışmanın konusu, orta çağ İslâm siyaset düşüncesinin altında yer alan siyaset türlerinde kaleme alınmış olan kitapların hem muhtevalarını hem de bölüm başlıklarını belirlemesinden ve ayrıca yeryüzünde devlet ve toplumdaki düzenin ve yapının ancak adalet kavramı vasıtasıyla insandaki düzen ve yapı ile gökyüzündeki düzen ve yapıya benzetebileceğinin kabul edilmesinden dolayı, ortaçağ i̇slâm siyaset düşüncesinin en temel, en önemli ve en merkezi kavramı olduğu düşünülen ve ifade edilen adalet dairesi kavramının uzun formudur.

Adalet dairesi kavramının uzun formunun dışında, çeşitli alt türleriyle birlikte, kısa formları da bulunmaktadır. Bu makale yalnızca uzun formu dikkate almaktadır, dolayısıyla, bu çalışmada, adalet dairesi kavramının kısa formları, incelemenin konusu dışında tutulmuştur. Adalet dairesi kavramının uzun formu, yazılı olarak yer aldığı ilk kaynağından, bir başka ifadeyle, başlangıcından Osmanlı dönemine ait XVI. asrın sonuna kadarki bir dönemle sınırlı kalacak biçimde, tarihsel ve felsefî yahut teorik olmak üzere iki yönden, açıdan ele alınıp incelenecektir.

Bu iki yöne veya açıya uygun olacak şekilde, makale de iki ana bölümden oluşmaktadır. Bu iki ana bölümden birinci ana bölüm, alt başlıkları olmaksızın çeşitli açılardan ele alınıp değerlendirilmek istenmiştir. İkinci ana bölümün ise, kendi içinde alt başlıkları, 
konuları ve problemleri söz konusudur. Kavramın tarihsel yönünü konu alan birinci bölümde, ilk olarak, uzun formun yer aldığı yazılı ilk kaynak ve uzun formun orta çağ İslâm siyaset düşüncesine nasıl, hangi yolla intikal ettiği tespit edilip açıklanacak ve bu tespitin ne anlama geldiği ya da sonucu ifade edilecektir. Ardından, İslâm siyaset düşüncesine intikal ettikten sonra uzun forma atıfta bulunan İslâm düşüncesine ait olan kaynakların, eserlerin türleri, bu eserlerin yazıldıkları İslâm dünyasındaki farklı ve çeşitli devletler ve coğrafyalar, siyaset metinlerinde uzun formun kaynağının nispet edildiği farklı şahıslar ile söz konusu kavramın temel unsurları hakkında bilgi verilecek ve bu tespitlerin anlamları, bir başka ifadeyle sonuçları ortaya konulacaktır. Kavramın felsefî veya teorik yönünü konu alan ikinci bölümde ise, birinci olarak, siyaset düşüncesine ait bir kavram olmakla birlikte, adalet dairesinin uzun formuna ait olan temel unsurların ve ilkelerin, Yeni Platoncu ya da Meşşaî felsefe çerçevesinde, klâsik bilişsel yahut rasyonel psikolojiye karşılık gelen nefs teorisi ve ahlâk felsefesi, doğa felsefesi veya fizik bilimi, evren ve kozmoloji anlayışı ile metafizikten kaynaklandığı gösterilecektir. Son olarak ise, adalet dairesinin uzun formunun, ilişkili olduğu devlet ve toplum düzeni ve yapısı ile bu devlet ve toplum yapısı ve düzeni içindeki önemi, anlamı ve işlevi açıklanacaktır.

\section{Tarihsel Açıdan Adalet Dairesinin Uzun Formu}

Adalet dairesi kavramına ait olan uzun formun yazılı olarak yer aldığı en erken tarihli kaynak, Kitâbü's-siyâse fí tedbîri'r-riyâse veya daha meşhur adıyla Sırrü'l-esrâr adlı eserdir. Sırrü'l-esrâr, orta çağda, hem İslâm ve hem de Batı dünyasında, Aristoteles'e ait olduğu kabul edilen, günümüzde ise ona ait olmadığı bilinen, aslı bilinmeyen, yani hem orta çağda ve hem de günümüzde aslı mevcut olmayan, buna rağmen, çok sayıda Arapça, Osmanlı Türkçesi ve Latince tercümesi olarak ifade edilen nüshası bulunan, miladî dokuzuncu asrın başlarında Yuhanna İbn el-Bıtrik tarafından, Yunanca veya Süryaniceden Arapçaya tercüme edildiği ve Abbasî halifesi el-Me'mun'a (ö. 833) sunulduğu kabul edilen, melikler, adalet, vezirler, kâtipler, vergi memurları, ordunun idaresi, savaş sanatı ve tılsım ilimleri, yıldızların sırları, taşların ve bitkilerin özellikleri gibi on bölümden teşekkül eden ve büyük oranda Büyük İskender'in İran fethi sırasında Aristoteles ile Büyük İskender arasında gerçekleştiği var sayılan mektuplaşmaları konu alan siyasetnâme ve nasihatnâme türü altına yerleştirilebilecek olan bir eserdir (Bedevî, 1954: 67-72; Manzalaoui, 1974: 147-257).

Adalet dairesi kavramının uzun formunun orta çağ i̇slâm düşüncesine intikal etmesi, Sırrü'l-esrâr adlı eserin Abbasîler döneminde, miladî dokuzuncu asrın başlarında, Arapçaya tercüme edilmesiyle gerçekleştiği söylenebilir. Orta çağ İslâm düşüncesine ait 
olan kaynakların, kitapların dikkate alınması durumunda, Sırrü'l-esrâr adlı eserden kaynaklanan adalet dairesi kavramına ait olan uzun formun yer aldığı en erken tarihli kaynak, Endülüs Emevî Devleti'nin (756-1031) Halifelik Dönemi'nde (929-1031) yaşamış olan İbn Cülcül'ün (ö. 994) Halife II. Hişam'ın (ö. 1009) özel hekimliğini yaptığı sırada, 987 tarihinde kaleme aldığı Tabakâtü'l-etıbbâ ve'l-hukemâ adlı doktorlar ve filozoflar hakkında bilgi veren tabakat (biyografi, ansiklopedi) türündeki eseridir (Karlığa, 1999: 403-404). İbn Cülcül'ün atıfta bulunduğu adalet dairesi kavramına ait olan uzun formun örneği, "ikinci Tabaka" bölümünde mevcut olan "Aristoteles" başlığı altında yer almaktadır (ỉbn Cülcül, 1985: 26).

Orta çağ İslâm düşüncesine ait olan kaynakların göz önünde bulundurulması durumunda, adalet dairesi kavramına ait olan uzun formun örnekleri, tespit edebildiğim kadarıyla, toplam yirmi eserde yer almaktadır. Bu toplam yirmi eserden beşi tabakât ve tarih türüne aittir: İbn Cülcül'ün (ö. 994) Tabakâtü'l-etıbbâ ve'lhukemâ adlı eseri (Endülüs Emevîler dönemi, Endülüs). İbn Fâtik el-Âmirî’nin (ö. 1094) Muhtârü'l-hikem adlı eseri (Fâtımîler dönemi, Mısır). İbn Ebî Usaybia'nın (ö. 1269) Uyûnü'l-enbâ fí tabakâti'l-etıbbâ adlı eseri (Eyyûbîler dönemi, Dımaşk). Şehrezûrî'nin (ö. 1288'den sonra) Nüzhetü'l-ervâh adlı eseri (Irak). İbn Haldun'un (ö. 1406) Mukaddime adlı eseri (Hafsîler dönemi, Tunus). İkisi edeb veya âdâb olarak tanımlanması mümkün olan türe aittir: İbn Abdülber'in (ö. 1071) Behcetü'l-mecâlis adlı eseri (Endülüs Emevîler dönemi, Endülüs). Cemâleddin el-Vatvât'ın (ö. 1318) Gurerü'lhasâisi'l-vâdiha adlı eseri (Memlükler dönemi, Mısır). Altısı siyasetnâme yahut nasihatnâme şeklinde ifade edilebilecek olan türe aittir: Muhammed el-Kayrevanî'nin (ö. 1096) Kitâbü'l-işâre ilâ edebi'l-imâre adlı eseri (Murabıtlar dönemi, Mağrib). Şeyzerî'nin (ö. 1193) el-Menhecü'l-mes/ûk adlı eseri (Eyyûbîler dönemi, Taberiye). Herevî'nin (ö. 1215) Tezkiretü'l-Hereviyye fi'l-hiyeli'l-harbiyye adlı eseri (Eyyûbîler dönemi, Halep). Kureşî'nin (ö. 1254) el-'ikdü'l-ferîd adlı eseri (Eyyûbîler dönemi, Şam). İbnü'l-Haddâd'ın (ö. 1251 'den sonra) el-Cevherü'n-nefîs fí siyâseti'r-reîs adlı eseri (Musul). İbnü'l-Ezrâk'ın (ö. 1491) Bedâiü's-silk adlı eseri (Nasrîler dönemi, Endülüs). Birisi tasavvuf türüne aittir: İbnü'l-Arabî'nin (ö. 1240) Fütuhâtü'l-Mekkiyye adlı eseri (Mekke ve Dımaşk). Üçü ahkâmu's-sultâniyye veya şerî siyaset olarak tanımlanması mümkün olan türe aittir: İbn Cemâa'nın (ö. 1333) Müstenedü'l-ecnâd adlı eseri, Muhtasar fí fazli'l-cihâd adlı eseri ve Tahrîrü'l-ahkâm adlı eseri (Memlükler dönemi, Kahire). Birisi tasnîfu'l-ulûm (illimlerin sınıflandırılması) türüne aittir: Fahreddin erRâzî'nin (ö. 1210) Câmiu'l-ulûm adlı ilimler tasnifi eseri (Hârizmler dönemi, Hârizm). İkisi de amelî hikmet (ahlâk, ev idaresi ve siyaset olmak üzere üç ana bölümden meydana gelen pratik felsefe) türüne aittir: Devvânî’nin (ö. 1502) Ahlâk-ı Celâlî adlı 
eseri (Akkoyunlular dönemi, Şiraz). Kınalızâde'nin (ö. 1571) Ahlâk-ı Alâî adlı eseri (Osmanlılar dönemi, Şam) (Kömbe, 2014: 168-232).

Bu toplam yirmi eserden on yedi eserin dili Arapça, iki eserin dili Farsça (Câmiu'l-ulûm, Ahlâk-ı Celâli) ve bir eserin dili de Türkçedir (Ahlâk-ı Alâl). Bu toplam yirmi eser arasından beşi Endülüs ve Mağrip coğrafyalarında (Fas ve Tunus), birisi Fatımîler döneminde Mısır'da, dördü Eyyûbîler döneminde Taberiye, Halep, Şam ve Dımaşk bölgelerinde, birisi Hârizmşahlar döneminde Hârizm'de, ikisi Irak'ta, birisi Dımaşk bölgesinde, dördü Memlükler döneminde Mısır'da, birisi Akkoyunlular döneminde Şiraz'da ve birisi de Osmanlılar döneminde Şam bölgesinde kaleme alınmıştır. Bu toplam yirmi eserin büyük bir çoğunluğu adalet dairesi kavramına ait olan uzun formun kaynağını Aristoteles'e nispet etmektedir. Bununla birlikte, Şeyzerî ve Herevî, uzun formun kaynağının Kisra Enûşirvan'a ait olduğunu söylemektedir. Kureşî, uzun formun kaynağını Hz. Ali'ye dayandırırken, Vatvât, Enûşirvan'ın veziri Büzürcmihr'e nispet etmektedir. İbn Cemâa ise, uzun formun kaynağı hakkında yalnızca "bazı hukema ve ulema" ifadesini kullanmakla yetinmektedir (Kömbe, 2014: 233-235).

\section{Teorik veya Felsefî Açıdan Adalet Dairesinin Uzun Formu}

Orta çağ İslâm siyaset düşüncesinin, devlet ve toplum düzeninin ve yapısının muhtasar ve müfid (özlü ve faydalı) bir ifadesi olan adalet dairesi kavramı, daire ve küre kavramından neşet eden 'mükemmellik' (yetkinlik) ve 'bekâ' (süreklilik) anlamındaki ilkeleri üzerinden modern öncesi, klâsik, Yeni Platoncu ve Meşşaî felsefe bağlamında, doğa felsefesi ya da fizik bilimi, geometri açısından matematik bilimi, kozmoloji veya evren tasavvuru ve metafizik düşüncesiyle ilişkili olduğu gibi, aynı zamanda ve aynı şekilde, Yeni Platoncu felsefe ve Meşşaî felsefe çerçevesinde, adalet kavramından kaynaklanan 'birlik' (vahdet) ve 'uyum, orta ve denge' (vasat, itidal) ilkeleri üzerinden ise klâsik bilişsel veya rasyonel biçiminde tanımlanabilecek olan psikolojiye karşılık gelen nefs teorisi, nefs teorisi üzerine bina olunan ahlâk felsefesi, kozmoloji ve metafizikle ilişki içindedir.

\subsection{Küre ve Daire Kavramı}

Modern öncesi dönemde, orta çağlar boyunca ve Antik dönemde, klâsik geometride, küre, en, boy ve derinlik olmak üzere üç boyutlu şekillerin en mükemmeli ve en süreklisi olarak tasavvur edilmiştir. Daire ise, en, boy ve derinlikten oluşan üç boyuta sahip olan kürenin en ve boydan meydana gelen ve dolayısıyla derinlik olarak üçüncü boyuttan yoksun olan bir kesiti anlamına gelir. Bundan dolayı, varlıkların en mükemmeli ve en süreklisi olarak kabul edilen Tanrı, geometrik şekillerin en 
mükemmeli ve en süreklisi olan küreye benzetilmiş ve küreyle temsil edilmiştir (Fazlıŏlu, 2012: 20-21).

Aynı şekilde, klasik kozmoloji, fizik bilimi (doğa felsefesi) ve geometri (matematik bilimi) söz konusu olduğunda, ay üstü evreni meydana getiren göksel varlıkların (akıllar, nefsler), gök kürelerinin (gezegenler) de Tanrı'ya benzer şekilde, küre biçiminde tasavvur edilmeleri ve varlık mertebesi (ontolojik) olarak, Tanrı'ya yakın olan bir varlık alanında bulunuyor olmaları ve dairesel (müstedir) harekette bulunmaları açısından, yetkinlik (kemâf) ve süreklilik (bekâ) sahibi oldukları kabul edilmiştir. Buna karşılık, ay altı evrene karşılık gelen dünyadaki, yeryüzündeki varlıkların ise, doğrusal yahut çizgisel (müstakim) bir harekete sahip ve varlık mertebesi (ontolojik) açısından da Tanrı'ya uzak olan bir varlık alanında bulunuyor olmaları yönüyle, eksik (nâkıs) ve süreksiz (bir süreliğine var olma ve daha sonra yok olma), yani oluş ve bozuluş (kevn ve fesad) içinde oldukları düşünülmüştür.

Mükemmellik (yetkinlik) ve süreklilik (bekâ) anlamındaki ilkeler, küreden ve kürenin dairesel hareketinden eksiklik ve süreksizlik, oluş ve bozuluş ise, doğrusal olmaktan ve doğrunun çizgisel hareketinden kaynaklanır. Klasik fizik biliminde, doğa felsefesinde, hareket, bir yönüyle, dairesel (müstedir) ve doğrusal ya da çizgisel (müstakim) olmak üzere ikiye ayrılırdı ve dairesel hareket mükemmel hareket, doğrusal yahut çizgisel hareket ise eksik hareket olarak kabul edilirdi. Dairesel hareket, hareketin bir noktadan başlayıp tekrar aynı noktada sona ermesi, dolayısıyla hareketin başladığı ve son bulduğu noktanın aynı olması ve bir araya gelmesi yani hareketin tamamlanması anlamına gelir. Bundan dolayı, mükemmellik, yetkinlik hareketin tamamlanması demektir ve ancak kürede, dolayısıyla ay üstü evreni oluşturan gök kürelerinde, göksel varlıklarda (akıllar ve nefsler) olduğu gibi, dairesel bir harekete sahip olmakla mümkündür. Buna karşılık, doğrusal harekette hareketin yönü çizgisel olduğu, yani hareketin başladığı nokta ile bittiği nokta aynı olmadığı, bir araya gelmediği için doğrusal yahut çizgisel hareket, dolayısıyla, ay altı evreni, dünyayı, yeryüzünü meydana getiren doğrusal hareket sahibi olan varlıklar (taşlar, bitkiler, hayvanlar, insanlar), tamamlanmaktan mahrumdur ve hep eksik kalmak durumundadır. Aynı şekilde, süreklilik de dairesel hareketle ve bundan dolayı da küreyle doğrudan ilişkili olarak görülmüştür. Küre, çeşitli kategoriler içerisinde konum kategorisi altında yer alır, yani bir düzleme ancak bir noktadan temas eder, bu yüzden, düzlemin içinde yer almaz, çünkü düzlemin içinde yer almak, o düzleme en az iki noktadan temas etmek anlamına gelir. Küre, bir düzlemde ikinci noktaya temas eder etmez önceki konumunu terk edip yeni bir konuma geçerek sürekli olarak varlığını devam ettirir. Bundan dolayı, küre, dolayısıyla, ay üstü evreni oluşturan gök küreleri ve göksel varlıklar, bir düzlemde, bir 
noktada, konum kategorisinde yer almak ve dairesel bir şekilde hareket etmek suretiyle süreklilik kazanmaktadırlar. Buna karşııı, doğru, bir düzleme en az iki noktadan temas eder, bu yüzden düzlemin içinde yer alır, konum kategorisiyle değil, nicelik, nitelik ve mekân kategorileriyle ilişkilidir, yani dünyayı, ay altı evreni, yer yüzünü oluşturan ve doğrusal harekete sahip olan varlıklar, nicelik, nitelik veya mekân açısından sürekli bir değişime, oluş ve bozuluşa (süreksizliğe) tâbidirler (Cündioğlu, 2007: 25-32, 41-43, 76-79; Macit, 2006: 183-195, 203-233; İbn Sina, 2004: 17, 33-39, 103-104, 115134; İbn Sina, 2010: 28-39).

\subsection{Adalet Kavramı}

Adalet kavramı, benzer olan şeyler veya varlıklar arasında sayısal, yani aritmetik bir eşitlik, benzer olmayan şeyler ya da varlıklar arasında ise orantısal, yani geometrik bir denklik vasıtasıyla orta olan noktayı (vasat) bulma ve benzer olan şeyler ile olmayanların yerlerini, konumlarını, mertebelerini belirleyerek onları hak ettikleri konumlarına yerleştirmeyi ifade eden birlik ile her bir varlığın ve nefs ile devlete ve topluma ait olan her bir gücün kendi konumunun gerektirdiği işlevi ve görevi yerine getirmesi ve bir alttaki varlığın ve gücün bir üstteki varlığa ve güce itaat etmesi neticesinde varlıklar ve nefs ile devlet ve topluma ait olan güçler arasında ortaya çıkan uyum ve denge (itidal) anlamlarına geldiği ifade edilmiştir. (İbn Miskeveyh, 1964: 19).

Birlik ve uyum anlamında adaletin kaynağı, mutlak anlamda ve metafizik açıdan, bir olana karşılık gelen Tanrı'dır. Varlıklar ve nefs ile devlete ve topluma ait olan güçler arasında var olması istenen adaletin derecesinin, bu varlıkların ve güçlerin mutlak bir olan Tanrı'dan aldıkları birlik, uyum ve denge payına uygun bir biçimde gerçekleşmesinin mümkün olacağı düşünülmüştür. Modern öncesi, klâsik doğa felsefesi, fizik bilimi ve kozmoloji anlayışı açısından bakıldığında, ay üstü evreni meydana getiren göksel varlıklar ve gök küreleri arasındaki yapı ve düzen (nizâm), birlik, uyum ve dengeye dayanır, çünkü gök kürelerinin maddî yapısı, esîr (aither) adı verilen bir tek unsurdan meydana gelmiştir. Bu sebeple, bir tek unsurun olduğu yerde, birlik, uyum ve denge dışında bir başka şeyin var olmasının düşünülmesi mümkün değildir. Buna karşılık ise, ay altı evreni, dünyayı, yeryüzünü oluşturan varlıklar arasındaki yapı ve düzen (nizâm) ise, çokluğa, çatışmaya ve kargaşaya dayanır, çünkü bu varlıkların maddî yapıları ya da tabiatları anlamına gelebilecek olan mizaçları, birbirine zıt ve birbiriyle sürekli çatışma halinde olan ateş, hava, su ve toprak şeklindeki dört ana unsurdan (anâsır-ı erba'a) ve bu unsurlardan kaynaklanan sıcaklık, soğukluk, ıslaklık ve kuruluk olmak üzere dört temel nitelikten meydana gelmiştir (ibn Miskeveyh, 1964: 12-14; Tusî, 2007: 112). 
Klâsik bilişsel, rasyonel psikolojiye karşılık geldiği söylenebilecek olan nefs teorisi açısından bakılması durumunda, adalet kavramı, Platoncu çerçevede, insan nefsinin, bir başka ifadeyle, insanî düşünen nefse ait olduğu kabul edilen (nâtık nefs) akıl, öfke (gazab) ve arzu (şehvet) güçlerinden her birinin kendi işlevini yerine getirmesi neticesinde insan nefsinin güçleri arasında ortaya çıkan birlik, uyum ve denge (vasat ve itidal) anlamına gelir.

Meşşaî felsefe bağlamında, orta çağ İslâm ahlâk felsefesi ve nefs teorisi açısından, insan, Aristotelesçi madde ve suret ilişkisinden hareketle, nefs ile beden olmak üzere birbirinden bağımsız ve farklı yapılara ve özelliklere sahip olan iki cevherin birleşmesinden meydana gelen bir varlık olarak tanımlanmıştır. Nefs, cismanî, fiziksel, maddî olmayıp nuranî, soyut, aklî, manevî bir yapıya ve özelliğe sahip olan bir varlıktır. Beden ise, akıldan pay almayacak biçimde, cismanî, fiziksel ve maddî bir yapıya ve özelliğe sahip olan bir varlıktır. Nefsin öfke ve arzu güçleri bedenle doğrudan bir ilişki içindedir. Akıl ise, esas itibariyle, insanî nefse karşılık gelir ve bedenle doğrudan değil, ancak öfke ve arzu güçleri vasıtasıyla dolaylı bir tarzda ilişki kurabilir.

Yukarıda belirtildiği üzere, insan nefsine ait olan akıl, öfke ve arzu güçleri arasında olması arzu edilen söz konusu bu birlik, uyum ve denge, en üstte yer alan ve yönetici konumunda bulunan akıl gücünün en altta yer alan ve yönetilen konumunda bulunan ve bedenle doğrudan ilişkili olan arzu gücünün aşırı, ölçüsüz ve sınırsız duyusal, bedensel, maddî isteklerini arada yer alan ve akıl gücünün yardımcısı olan öfke gücünün yardımıyla kontrol altında tutması ve arzu gücüne boyun eğdirmesi neticesinde gerçekleşebileceği mümkün olarak görülmüştür. Ahlâk felsefesi açısından bakılması durumunda adalet kavramı, insanın, hem nefsin akıl, öfke ve arzu güçlerinden kaynaklanan ve aşırı çok (ifrât) ve aşırı az (tefrit) şeklinde iki aşırı uca karşılık gelen iki reziletin (erdemsizlik) nicelik (miktar) ve nitelik (amaç) bakımından, insandan insana değişecek ve dolayısıyla göreceli olacak şekilde, orta noktasını (vasat) ifade eden hikmet, cesaret ve iffet erdemlerine uygun huylar veya melekeler elde etmesi ve davranışta bulunması, hem de temel erdemler olarak ifade edilen hikmet, cesaret ve iffet erdemlerinin hepsine sahip olması, bir başka ifadeyle, hikmet, cesaret ve iffet şeklinde üç ana erdemin bir insanda toplanması, bir araya gelmesi anlamına gelir ki bu durumda, dördüncü ana erdem olarak adalet erdeminin ortaya çıkması gerçekleşir (Kınalızâde, 2007: 64-66, 74-75, 101-104, 111-112, 117-121).

\subsection{Siyaset Felsefesi Açısından Adalet Dairesinin Uzun Formu}

Ay altı evrene karşılık gelen yeryüzünde, dünyada, doğal halde bulunması durumunda, çokluğa, çatışmaya, kargaşaya, eksikliğe ve süreksizliğe dayanan toplumsal düzenin ay 
üstü evren ile insan nefsindeki birliğe, uyuma, dengeye, mükemmelliğe ve sürekliliğe dayanan düzene ancak adalet dairesi kavramı vasıtasıyla benzetilebileceği düşünülmüştür (Ibn Miskeveyh, 1964, 15). Bundan dolayı, genelde adalet dairesi ve özelde de adalet kavramı, siyaset düşüncesi yazarları tarafından, orta çağ siyaset düşüncesinin en merkezi ve önemli kavramı olarak kabul edilmiştir.

Sırrü'l-esrâr adlı eser ile İbn Cülcül'ün Tabakât adlı eserinde ortak olan adalet dairesi kavramına ait olan uzun formun örneği şu şekilde nakledilmektedir: (Sırrü'l-esrâr, 1954: 127; İbn Cülcül, 1985, 26).

- el-Âlem bustân siyâcuhu ed-devle (Âlem bir bahçedir, onun çiti devlettir).

- ed-Devle sultân tahcubuhu es-sünne (Devlet iktidardır, onu muhafaza eden sünnettir).

- es-Sünne siyâse yüsevvisuhâ el-melik (Sünnet bir siyasettir, onu hâkim kılan meliktir).

- el-Melik râ'i ya'duduhu el-ceyş (Melik bir çobandır, ona yardım eden ordudur).

- el-Ceyş a'vân yükeffiluhum el-mâl (Ordu muhafızdır, onların ihtiyaçlarını karşılayan maldır).

- el-Mâl rızk tecma'uhu er-raiyye (Mal bir rızıktır, raiyyeden toplanır).

- er-Raiyye abîd yete'abbeduhum el-adl (Raiyye itaat edendir, onu itaatkâr kılan adalettir).

- el-Adl me'lûf ve hüve salâhü'l-âlem (Adalet âlemdeki birlik, uyum ve dengenin, yani iyiliğin sebebidir).

Adalet dairesi kavramına ait olan uzun formu meydana getiren ana unsurlar: 'devlet' (adalet dairesinin bazı örneklerinde geçtiği haliyle 'mülk'; iktidarın farklı aileler veya hanedanlar arasında sürekli olarak elden ele dolaşması ya da belirli bir yönetici kesimin elinde süreklilik kazanan ve kurumsallaşan iktidar gücü), 'sünnet' (adalet dairesinin bazı örneklerinde geçtiği haliyle 'şeriat'; dinî, aklî, örfî, sultanî yasa), 'melik', 'ordu', 'mal' (savaşlardan elde edilen ganimetlere, tarıma ve toprağa bağlı üretime ve vergilere dayanan devlet gelirleri), 'raiyye' (adalet dairesinin bazı örneklerinde geçtiği haliyle 'reaya', 'tebaa'; mutlak anlamda yönetilen, yönetime hiçbir biçimde katılması mümkün olmayan toplum, halk kesimi) 'adalet', 'âlemdeki salâh' (adalet dairesinin bazı örneklerinde geçtiği haliyle 'salâh-ı cihan', 'hayatü'l-âlem'; devlet ve toplum idaresinde birlik, uyum ve denge, yani iyi anlamında adalet vasıtasıyla ve adaletin gerçekleşmesi neticesinde mükemmellik ve süreklilik kazanan düzen ve yapı).

Adalet dairesi kavramına ait olan uzun formunu meydana getiren bu temel unsurlar, esas itibariyle, İran veya Sasanî siyaset, devlet ve toplum düşüncesi (Erdeşir, 1967: 63; 
BalcI, 2016: 80-83; Wiesehofer, 2003: 235-260)ile Platon'un siyaset felsefesinden kaynaklanan (Platon, 1992: 59-67, 102-103, 130-131, 151) ve Abbasîler döneminde ve sonrasında, İran'dan ve Antik Yunan'dan yapılan tercümelerin yanı sıra, Müslüman yazarlar tarafından bu tercümelerin muhtevasına fakat özellikle ve daha ziyade yapısına uygun olarak kaleme alınan telif eserler vasıtasıyla İslâm siyaset düşüncesine uyarlanan ve Osmanlı siyaset düşüncesinde de yaygın olarak atıfta bulunulan devlet ve toplum yapısı ve düzeni ile bu yapı ve düzeni teşkil eden kesimlere karşılık gelir. Buna göre, devlet ve toplum yapısı ve düzeni, modern öncesi klâsik doğa felsefesinin, fizik biliminin ilkesine uygun olarak, yani ay altı evrene karşılık gelen yeryüzünde, dünyada mevcut olan varlıkların (varlığa gelme sırasına göre, taşlar, bitkiler, hayvanlar ve insanlar) maddî yapılarını oluşturan tabiatlarının ya da mizaçlarının birbirine zıt tabiatlı ve birbiriyle sürekli olarak mücadele halinde olan dört unsura (ateş, hava, su, toprak) karşılık gelecek biçimde dörtlü olarak ve şu şekilde tasavvur edilmiştir: 'Kalem ehli' (âlimler, kadılar, kâtipler, maliyeciler, tabipler, şairler, müneccimler ve mühendisler), 'Şemşir ehli' (emirler, bahadırlar ve sipahiler) ve 'raiyye' (reaya, tebaa) olan 'tüccar, hiref ve sanayi tâyifesi' ile 'ziraat ve ekinci tâyifesi' (Kınalızâde, 2007: 485-488). Orta çağ İslâm siyaset düşüncesi içinde kaleme alınmış olan farklı siyaset metinlerinde, devlet ve toplum yapısını ve düzenini meydana getiren kesimlerin adlandırmalarıyla ilgili bazı farklılıklar olmakla birlikte, dörtlü olan yapı ve düzen hiçbir değişikliğe uğramamıştır.

Sultan, melik, padişah veya halife, devlet ve toplum yapısının ve düzenin dışında ve üstünde ya da merkezinde yer almakta olup devlet ve toplum yapısının ve düzeninin varlık sebebi ve ilkesidir. Seçkinler seçkini olarak kabul edilmişlerdir (ehassü'l-havas). En üstte yer aldığı için mutlak âmirdir (yönetici), yani hiçbir biçimde yönetilen konumunda olması ve yönetilmesi düşünülemez. Raiyyeyi (toplum, halk) doğrudan değil, devlet bürokrasisi vasıtasıyla, yani dolaylı olarak yönetir. Ay üstü evrende Tanrı'ya, insan nefsinin güçleri arasında ise akıl gücüne benzer yahut karşılık gelir. Kalem ve Şemşir ehli, devlet bürokrasisini, dolayısıyla da devleti oluştururlar. Seçkin olarak kabul edilmişlerdir (havas). Ortada yer aldıkları için sultan veya halifeyle ilişkisi açısından memur (yönetilen), raiyye ile ilişkisi açısından âmir (yönetici) konumunda bulunurlar. Vergiden muaf tutulmuşlardır. Maaşlarını sultan ve halifeden alırlar. Ay üstü evrende gök kürelerine, göksel varlıklara, insan nefsinin güçleri arasında öfke gücüne benzerler veya karşılık gelirler. Kalem ehli, topluma can ve hayat verdikleri için dört unsur arasından suya karşılık gelir. Şemşir ehli, asker kesimi olması bakımından, yakıcı ve yıkıcı olmaları yönüyle, dört unsur arasından ateşe karşılık gelirler. Köylü, çiftçi, zanaatkâr ve tüccar kesimine karşılık gelen raiyye ise toplumu, halkı oluştururlar. Seçkin olarak kabul edilmezler (avam). En altta yer aldığı için mutlak memur (yönetilen) 
konumundadırlar, yani hiçbir biçimde yönetici konumunda olması ve yönetmesi düşünülemez. Silah taşımaları yasaktır. Vergi vermek, üretmek ve itaat etmekle yükümlüdürler. Buna karşılık, güvenliğinin ve üretimle ilgili ihtiyaçlarının karşılanmasını ve genelde sivil veya askerî devlet memurları özelde ise vergi memurları hakkında dile getirdikleri şikayetlerinin dinlenilmesini beklerler. Ay altı evreni meydana getiren yeryüzündeki, dünyadaki cismanî, maddî ve duyusal varlıklara, insan nefsinin güçleri arasında ise arzu gücüne benzetilmişlerdir. Köylü ve çiftçi kesimi, dört unsur arasından toprakla meşgul olmaları sebebiyle, toprağa karşılık gelir. Tüccar ve zanaatkâr kesimi ise, havanın sürekli olarak dolaşmasına benzer şekilde, paranın ve malların dolaşımı sebebiyle, dört unsurdan havaya karşılık gelir.

Siyaset felsefesi, devlet ve toplum düşüncesi ve adalet dairesi kavramı açısından, adalet kavramı, dağıtıcı ve düzeltici yönüyle sultan-halifenin, yapının ve düzenin merkezinde veya dışında bulunmasından dolayı, devleti ve toplumu oluşturan kesimlere karşı eşit mesafede yer alması, bu kesimleri bulunmaları gereken doğal yerlerine yerleştirmesi ve bu doğal yerlerinde tutması ve her birinin doğasına ve erdemine uygun olan işlevi yerine getirmesini sağlaması, birbirinin işlevine karışmalarına izin vermemesi, her birine bulunduğu mertebeye, konuma göre hak ettiği ölçüde malları, paraları, makamları ve şerefleri dağıtması, kesimler arasındaki geçişe mümkün olduğu kadar izin vermemesi, köylü ve çiftçi kesiminden gayrı meşru olarak vergi toplayan, topraklarına, hayvanlarına ve mallarına zarar veren sivil ya da askerî vergi memurlarını cezalandırması anlamlarına gelir. İnsanî hâkim olan sultan-halife, siyasî, sosyal, iktisadî ve hukukî anlamda adaletin dağıtıcı ve düzeltici yönlerini para (dirhem) ve ilahî kanun vasıtasıyla gerçekleştirmesi esas olandır (Tusî, 2007: 113-125).

Siyaset düşüncesiyle ilgilenen yazarlar tarafından, devlet ve toplum düzeninde ve yapısında iyi olanı ifade eden birlik, uyum ve dengenin, ancak adalet kavramı vasıtasıyla ve adaletin tesisi neticesinde gerçekleşebileceği var sayılmıştır. Birlik, uyum ve dengenin (iyi olanın) muhafaza edilmesi ve bozulmaması neticesinde ancak devletin ve toplumun mükemmellik ve süreklilik kazanacağı düşünülmüştür. Devleti ve toplumu oluşturan kesimlerden her birinin kendi doğal yerinde kalmasının ve doğasına uygun olan işi yapmasının ve kendisine ait olan işlevi yerine getirmesinin iyi, buna karşılık kendi doğal yerini terk edip bir başka kesimin işini yapmaya ve işlevini yerine getirmeye kalkmasının ise kötü olarak görülmesi, Aristoteles'in ve İbn Sina'nın doğa felsefesine ait hareket teorisiyle ve kökeni Platon ile Aristoteles'in ahlâk felsefesine, yani onların uzlaştırılması anlamında Yeni Platoncu felsefeye dayanan İslâm ahlâk felsefesinde mevcut olan erdem (fazilet) teorisiyle ilişkilidir. Meşşâî felsefenin fizik, doğa anlayışına göre, doğal yerlerinde bulunmayan doğal şeyler, doğal yerlerine 
ulaşmak için hareket ederler ve doğal yerlerine gelip yerleştiklerinde ise hareket son bulur. Doğal bir şeyin doğal yerinde kalıp hareket etmemesi ve değişmemesi iyi ve asıl olanı ifade eder, buna karşılık hareket ederek doğal yerini terk edip değiştirmesi ise kötü ve arızî olanı ifade eder. Meşşâî felsefenin ahlâk teorisine göre ise, erdem, bir şeyin veya insanın doğasına uygun olan işlevi anlamına gelir. İyi ise, bir şeyin veya insanın erdeme uygun olacak biçimde etkinlikte ve fiilde, davranışta bulunması anlamına gelir.

Adalet dairesi kavramına dayanan devlet ve toplum düzeninde ve yapısında, mülk ve devlet ile din arasında tasavvur edilen ilişki, kaynağı Sasanî imparatorluğunun kurucusu ve hem rahip hem de kral olan Erdeşir'de mevcut olduğu gibi, aynı zamanda, Mezopotamya, İran, Sasanî siyaset, devlet ve toplum düşüncesinin ürünü olan, söz konusu olan bu düşünceyi yansıtan ve ikiz kardeşlik adı verilen bir ilişki üzerine inşa edilmiştir. (Erdeşir, 1967: 53). İkiz kardeşlik ilişkisi, felsefî olarak bakılması durumunda, kategoriler açısından, nispet veya ilişki (izafet) kategorisi altında yer alır, yani iki şey var olmak için birbirine zorunlu olarak ihtiyaç duyar, bu iki şeyin varlığı birbirine bağlıdır, biri olmadan diğeri varlığını sürdüremez. Din ile mülk ve devlet arasında da bu türden bir ilişki söz konusudur. İkiz kardeşlik ilişkisine göre, din temel (üss, imâd), mülk ve devlet ise muhafızdır (hâris). Mülk ve devlet dini korur ve dinin yaşanmasını temin eder, din ise mülkün ve devletin dinî ve hukukî meşruiyetinin gerçekleşmesini sağlar. Din ile mülkün ve devletin birlikteliğini ise, dinî ve hukukî otorite ile siyasî ve askerî gücü kendisinde birleştiren sultan, melik, padişah veya halife temsil eder.

Adalet dairesi kavramı, devlet ile toplumun birlikteliği ve ayrılmazlığı düşüncesini de zorunlu olarak görür. Devlet ile toplumun birlikteliği ve ayrılmazlığı düşüncesinin, İslâm öncesi Türk siyaset düşüncesi açısından, gökyüzü ile yeryüzünün 'kutsal dağ' veya 'dünya ağacı' adı verilen bir direkle, eksenle kopmayacak bir biçimde birbirine bağlı olduğu anlayışıyla ilişkilendirilmesi mümkündür. (Bayat, 2007: 34-63; Çoruhlu, 2012: 97-105) Meşşaî felsefenin doğa, fizik kavrayışı açısından ise, 'madde' ve 'form', 'kuvve' (potansiyel) ve 'fiil' (aktüel, gerçeklik) teorisi ile fâil sebep, gaye sebep, maddî sebep ve formel sebep olmak üzere 'dört sebep' teorisiyle açıklanması mümkündür. (İbn Sina, 2004; Macit, 2006) Madde ile formun ay altı evren olan yeryüzünde, dünyada fiilî olarak, gerçeklik kazanarak var olabilmesi için birleşmeleri gerekir. Aktif ve ay üstü evrende fiilî varlığa sahip olan formun pasif ve kuvve halinde varlığa sahip olan maddeye etkide bulunması neticesinde madde, kuvve, potansiyel halinde varlık durumundan çıkıp fiilî olarak varlık, gerçeklik kazanır. Formun karşılığı devlet, maddenin karşılığı ise toplumdur, halktır. Aktif ve fiilî varlık sahibi olan devlet topluma, halka etkide bulunduğunda ancak pasif ve kuvve halinde potansiyel varlık sahibi olan 
toplum veya halk fiilî olarak var olabilir ve gerçeklik kazanabilir. Dört sebep teorisi çerçevesinden bakılması halinde ise, sultan, melik, padişah veya halife fâil (etkin olan) sebep, âlemin salahı (devlet ve toplumun birlik, uyum ve denge kazanmasıyla ortaya çıkan mükemmellik ve süreklilik) gâî (amaç olan) sebep, devlet sûrî (formel, form olan) sebep ve toplum ise maddî (edilgen olan) sebep konumundadır.

\section{Sonuç}

Adalet dairesi kavramına ait olan uzun form, orta çağ İslâm siyaset düşüncesine dışarıdan girmiş olan bir kavram olmakla birlikte, çeşitli coğrafyalarda kurulan çok sayıdaki devletlerde kaleme alınan farklı türdeki eserler vasıtasıyla, orta çağ İslâm siyaset düşüncesini meydana getiren pek çok tür içinde yaygınlık kazanmış ve büyük bir kabul görmüş olduğu kesin bir biçimde söylenmelidir. Orta çağ İslâm siyaset düşüncesinin formül, yani muhtasar ve müfid halindeki (kısa fakat özlü ve faydalı) bir ifadesi olan adalet dairesi kavramının uzun formu, daire ve küre kavramından, dolayısıyla dairesel hareketten kaynaklanan 'mükemmellik' (yetkinlik) ilkesi ve 'süreklilik' (bekâ) ilkesi olmak üzere iki temel ilke vasıtasıyla, klasik doğa felsefesi ve fizik bilimi, geometri yoluyla matematik bilimi, kozmoloji, evren anlayışı ve metafizik tasavvurla ilişkili olduğunu söylemek gerekirken, aynı şekilde ve aynı zamanda, adalet kavramından ve ay üstü evreni oluşturan gök kürelerinin yapılarının saydam ve latif bir özelliğe sahip olan ve esir adı verilen bir tek unsurdan meydana gelmesinden kaynaklanan 'birlik' ilkesi ile 'uyum' ve 'denge' ilkesi olmak üzere iki temel ilke vasıtasıyla da modern öncesi klâsik aklî, bilişsel, rasyonel psikolojiye karşılık gelen nefs teorisi, ahlâk felsefesi veya pratik felsefe (amelî hikmet), kozmoloji ve metafizikle ilişki içinde olduğu ifade edilmelidir. Ay altı evrene karşılık gelen yeryüzünde, yani dünyada ise, çizgisel veya doğrusal hareket ile cismanî, maddî ve duyusal bir özelliğe sahip olan dört unsur sebebiyle ve doğal halde bulunması durumunda, çokluğa, çatışmaya, kargaşaya, eksikliğe ve süreksizliğe dayanan toplumsal düzenin ve yapının ay üstü evren ile insan nefsi ve bedenindeki güçler ve organlar arasındaki birliğe, uyuma, mükemmelliğe ve sürekliliğe dayanan düzene ve yapıya ancak adalet dairesi kavramı ve bu kavramı meydana getiren temel unsurlar ve ilkeler vasıtasıyla benzetilebileceği düşünülmüştür. Bundan dolayı, genelde adalet dairesi kavramının ve özelde de adalet kavramının, siyaset düşüncesi yazarları tarafından, orta çağ siyaset düşüncesinin en merkezi ve önemli kavramı olduğunun altı çizilmiştir. Bu çerçevede, adalet dairesi kavramına ait olan uzun formun, gelirlerinin büyük bir kısmı ile askerî ve toplumsal gücü tarıma ve toprağa bağımlı olan kara devletinin siyaset ve devlet ve toplum düşüncesinin bir ifadesi ve yansıması olduğunu söylemek mümkündür. 


\section{Kaynaklar}

Balcı, M. (2016). Taşa Kazınmış Sözler Islâm Öncesi Fars Öğüt Edebiyatı. İstanbul: Büyüyen Ay Yayınları.

Bayat, F. (2007). Türk Mitolojik Sistemi Ontolojik ve Epistemolojik Bağlamda Türk Mitolojisi-1. İstanbul: Ötüken Yayınları.

Bedevî, A. (1954). el-Usûlü'l-Yunaniyye li'n-nazariyyâti's-siyâsiyye fi'l-islâm. Kahire: Dârü'lkütübi'l-Mısrıyye.

Cündioğlu, D. (2007). Daire’ye Dair. İstanbul: Etkileşim Yayınları.

Çoruhlu, Y. (2012). Türk Mitolojisinin Ana Hatları. İstanbul: Kabalcı Yayınları.

Erdeşir. (1967). Ahd-i Erdeşir. nşr. İhsan Abbas. Beyrut: Dâru Sâdır.

İbn Cülcül. (1985). Tabakâtü'l-etıbbâ ve'l-hükemâ. thk. Fuad Seyyid, Beyrut: Müessesetü'rrisâle.

Karlığa, B. (1999). “ibn Cülcül”. Türkiye Diyanet Vakfı Islâm Ansiklopedisi. 19/403-404. İstanbul: TDV Yayınları.

İbn Miskeveyh. (1964). Risâle fî mâhiyeti'l-adl. An Unpublished Treatise of Miskawaih on Justice or Risala fi mahiyat al-adl li Miskawaih içinde. M. S. Khan (ed.). Leiden: E. J. Brill.

İbn Sina. (2004). Fizik, I. nşr. ve çev. Muhittin Macit ve Ferruh Özpilavcı. İstanbul: Litera Yayınları.

İbn Sina. (2005). Fizik, II. nşr. ve çev. Muhittin Macit ve Ferruh Özpilavcı. İstanbul: Litera Yayınları.

İbn Sina. (2010). Sema ve Âlem. nşr. ve çev. Harun Kuşlu ve Muhittin Macit. İstanbul: Litera Yayınları.

Kınalızâde, A. Ç. (2007). Ahlâk-ı Alâî. haz. Mustafa Koç. İstanbul: Klasik Yayınları.

Kömbe, ì. (2014). Adalet Dairesinin Teşekkülü ve Temel Kavramları. (Doktora Tezi, Marmara Üniversitesi, Sosyal Bilimler Enstitüsü, İstanbul).

Macit, M. (2006). Ibn Sina'da Doğa Felsefesi. İstanbul: Litera Yayınları.

Manzalaoui, M. (1974). "The Pseudo Aristotelian 'Kitâb Sirr al-asrâr'. Facts and Problems". Oriens, 23, 147-257.

Sırrü'l-esrâr. el-Usûlü'l-Yunaniyye li'n-nazariyyâti's-siyâsiyye fi'l-İslâm içinde, thk. Abdurrahman Bedevî. Kahire: Dârü'l-kütübi'l-Mısrıyye, 1954.

Tusî, N. (2007). Ahlâk-ı Nâsırî. çev. Anar Gafarov ve Zaur Şükürov. İstanbul: Litera Yayınları.

Tusî, N. (2012). Tahrîru usûli'l-hendese ve'l-hisâb. haz. ve nşr. İhsan Fazlıoğlu. İstanbul: Türkiye Yazma Eserler Kurumu Başkanlığı Yayınları.

Platon. (1992). Devlet. çev. Sabahattin Eyüboğlu ve M. Ali Cimcoz. İstanbul: Remzi Kitabevi. Wiesehofer, J. (2003). Antik Pers Tarihi. çev. Mehmet Ali İnci. İstanbul: Telos Yayıncılık. 